\title{
MANUFACTURE A NEW PROTOTYPE FOR CHOPPING RICE AND BARLEY STRAW FOR PRODUCING THE LITTER OF POULTRY HOUSES
}

\section{Aly Badawy Elnaggar* Amal Saleh**}

\begin{abstract}
The experimental work was carried out at Rice Mechanization Center, Meet Eldeebah village, Kafr Elsheikh governorate during harvesting session of 2013, to manufacture a new prototype for chopping rice and barley straw for producing the litter of poultry houses. The investigated variables were straw feed rate $(0.15,0.16,0.17$ and $0.18 \mathrm{~kg} / \mathrm{s})$ and chaff cutting length $(1.5,2.5,3.5$ and $5 \mathrm{~cm})$. The effect of these variables on the prototype productivity, cutting efficiency and the energy consumed, ware investigated, the main results summarized as: At $0.16 \mathrm{~kg} / \mathrm{s}$ feed rate, the productivity increased from 0.56 to $1.9 \mathrm{t} / \mathrm{h}$ for rice, and from 0.41 to 1.39 $t / h$ for barley when the cutting length increased from 1.5 to $5 \mathrm{~cm}$. At $1.5 \mathrm{~cm}$ cutting length, by increasing the feed rate from 0.15 to $0.18 \mathrm{~kg} / \mathrm{s}$, the prototype cutting efficiency decreased from 75 to $70 \%$ for rice, and from 81 to $75.6 \%$ for barley. The energy consumption rate of prototype decreased with increasing the feed rate of rice and barley straw. At $1.5 \mathrm{~cm}$ cutting length, by increasing the feed rate from 0.15 to $0.18 \mathrm{~kg} / \mathrm{s}$, the energy consumption rate of prototype decreased from 9.84 to $8.36 \mathrm{kw} . \mathrm{h} / \mathrm{t}$ for rice, and from 8.36 to $7.1 \mathrm{~kW} . \mathrm{h} / \mathrm{t}$ for barley. Evaluation of using of two cutting methods (manufacture and normal) of shaving woods, barley and rice straw as bedding materials and mixture between barley + rice straw (1:1) on broiler performance, carcass yields, Bedding characteristics and chemical analysis of broiler meat, the body weight gain and feed intake, as well as, feed conversion ratio were improved $(P<0.05)$ with the prototype cutting than normal cutting system.
\end{abstract}

\footnotetext{
* Researcher, Agricultural Engineering Research Institute, Egypt. ** Senior researcher, Animal Production Research Institute, Egypt.
} 


\section{INTRODUCTION}

7 mo most critical problems, which face the Egyptian farmer, especially after harvesting crops such as rice, cotton and other different farm crops The quantity of crop residues in Egypt reached about 25 million-ton per year and the national income might be increased with 1.6 billion LE/year if we success to recycle it(Elbery et al. 2004). The machine working performance, the main parameter is the cutting rotational speed; the cutting energy consumed in the harvesting process is much lower than the energy consumed in the crushing process due the effect of moisture content (Habib et al. 2002)

Forage harvesters classified into three distinct types, depending upon the method of cutting and discharging chopped material: cut and throw, cut and blow and flail types. On cut and throw harvester, the cutter head or flywheel does the entire cutting and delivers the crops to a wagon or truck. Cut and blow harvesters have a separate blower fan to deliver the crop to a wagon or truck. Material may be thrown directly into the fan by the cutter head or carried from the cutter head or flails to the fan by an auger (Fundamentals of machine operation, 1981). Crop residues are the plant materials that remain after crop have been harvested, they include cotton, and maize stalks and its shells, rice straw, bean straw residues of vegetables and residues of horticulture productions, etc. For that, reason it is very important to put policies for using the agricultural residues transformed ways to be used in the industry or animal production. Moisture content effects on the strength of plants, since the turgid pressure in the cells affects stem rigidity and strength. Near the base of rice straw at $62 \%$ moisture content, for example, the stems were 3.5 to 4 times heavier per unit length than near the top.

Investigated the effect of moisture content on the performance parameter of different mechanical methods of cutting and chopping cotton stalks. They concluded that by increasing the moisture content, the cutting efficiency increased, which means decreasing of the power requirement. (Nasr, 2005).

El-Awady et al. 1988 indicated that the cutting force is greatly affected by the moisture content of plants and by the increasing diameter of stalks. The cutting force decreased from 625 to $256.7 \mathrm{~N}$ by increasing the 
moisture content of stalk from 6.5 to $55 \%$, respectively for $9 \mathrm{~mm}$ diameter cotton stalk.

(Hashish et al 2002) found that the actual length of cut will approximate the theoretical length only when stalks feed in straight line, for nonoriented materials the actual length may average twice the theoretical setting.

Economic intensive broiler production is affected by many factors particularly environment and health status. However, cutting lengths process of litter materials for broiler production and good quality of litter properties had also an effect on the important traits of meat broiler production which related to growth, reproduction and rusticity, including resistance to digestive and respiratory diseases, as well as, behavioural of broiler improved breeds and strains (Burk et al., 1993).

The major advantage of uniformity cutting process is the reduction of moisture and dust content to a safe level that allows extending the storage of dried litters. Also, the process allows a substantial reduction in terms of mass, volume, packing requirement, storage and transportation costs with more convenience (Okos et al., 1992).

Many studies in which alternative materials were tested have demonstrated that bacteria, therefore may indirectly affect body weight and immune system of broiler chicks (Tien et al., 1998), as well as, bedding type can significantly affect growth performance and carcass quality of broiler (Malone et al., 1983 and Billgilli et al., 1999b). However, Toghyani et al. (2010) reported that litter materials had no significant influence on feed conversion, carcass yield, abdominal fat, gizzard, intestine, ceca and lymphoid percentage.

The main objectives of the present study were manufacture and evaluate new prototype cylinder chopping able to cut the rice and barley stalks to suitable lengths used for bedding.

\section{MATERIALS AND METHODS}

This study was carried out at RMC, AEnRI, at Kafrelsheikh Governorate during the period from November to December 2013, to manufacture and evaluate new prototype cylinder chopping able to cut the rice and barley stalks to suitable lengths used for bedding. 


\section{Chopping manufactured prototype}

Prototype specifications were as follows: Cutting system is cylindrical type and precision cut. Both Feeding and throwing direction are radial. The principal dimensions of the prototype are: $185 \mathrm{~cm}$ length; $95 \mathrm{~cm}$ width and $160 \mathrm{~cm}$ height. Growth weight was $200 \mathrm{~kg}$. Power source was by Electric motor (10 kw-3000 rpm) as shown in Figure (1).

\section{Prototype Element:}

1. Power transmission system:

The power source is electric motor $10 \mathrm{~kW}$ turn the prototype through $\mathrm{V}$ belts and pulleys runes the cutting cylinder and sprockets and chain to runes the feeding system.

2. Feeding System:

The power feeding drum fixed 1 in the opening gate, it derived the feeding drum conveyer, 2. Feeding drums 3 (4 units) fixed in parallel turned flat scraping conveyer belt 4 in the feeding direction as shown in Figure (2).

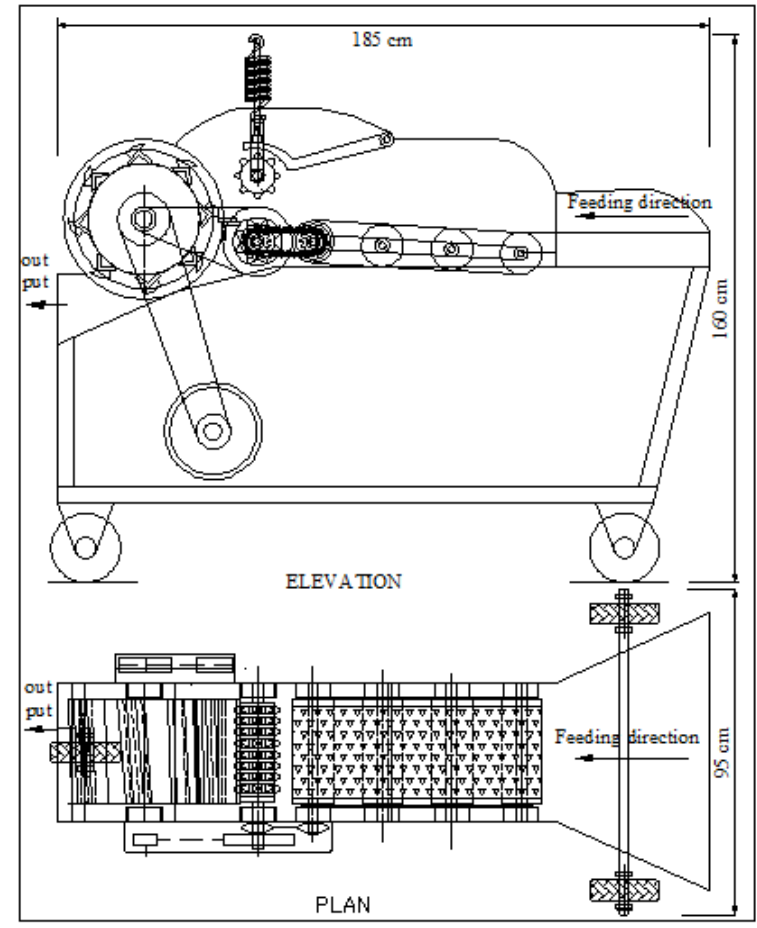

Figure 1: Construction of prototype chopper. 
Compact drum with flying ax 6 support upper the feeding drum separated gap (opening gate), it is covered by cap 6 to guide the stalks for cutting. Spring displacement 7 press drum 6 down keep it contacts with the feeding material.

\section{Cutting System:}

Rotating cylinder 1 (30 cm diameter, $30 \mathrm{~cm}$ width) with 8 knives fixed on its surface, the knives distributed regular, it is inclined $\left(10^{0}\right)$ make helical shape. Fixed knife 3 support in the end of the opening gate paralleled to the cutting cylinder ax making very narrow clearance with the rotating knives as shown in Figure (3).

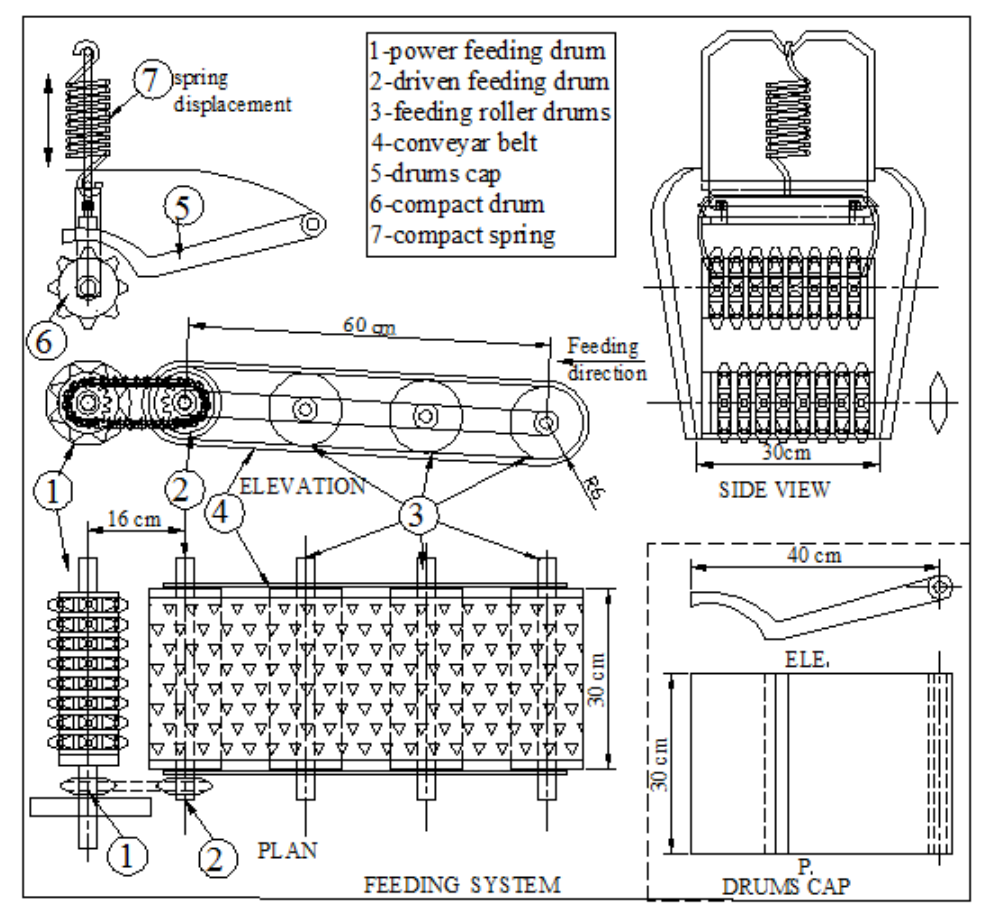

Figure 2: Prototype feeding system.

\section{Experimental layout:}

The manufactured chopping prototype was evaluated through studding the following factors on the prototype performance:

The main factors were, $0.15,0.16,0.17$, and $0.18 \mathrm{~kg} / \mathrm{s}$ straw feed rates, while the sub factors were, $1.5,2.5,3.5,5 \mathrm{~cm}$ chaff cutting lengths. 


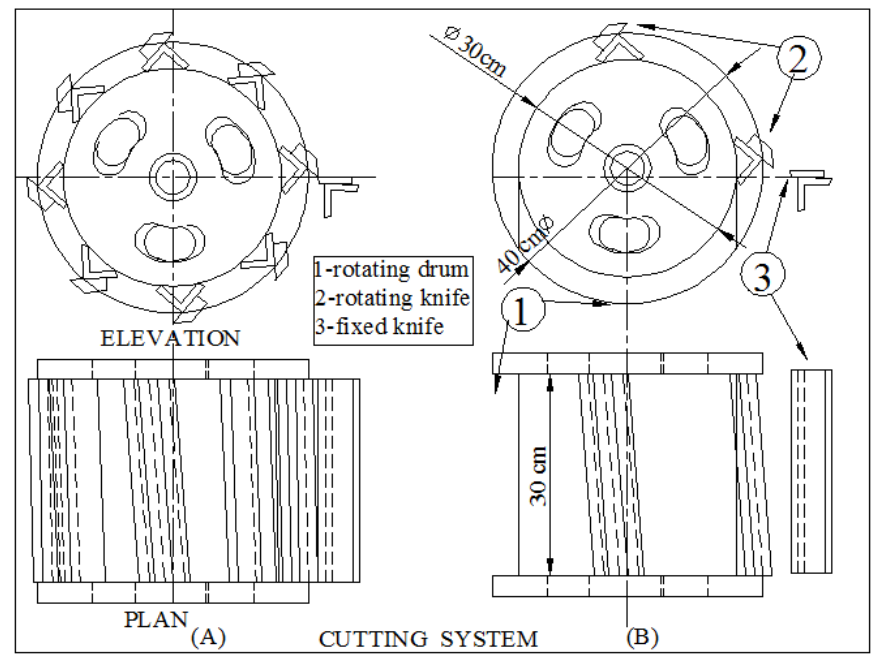

Figure 3: Prototype cutting system

\section{Cutting efficiency, \%:}

The cutting length of final product is an important parameter to evaluate the performance of chopping process. The cutting efficiency can be calculated according to:

Cutting efficiency $=\frac{\mathrm{S}_{\mathrm{a}}}{\mathrm{S}_{\mathrm{b}}} \times 100, \%$

Where: $S_{b}=$ the mass of the chopped before segregation, $g$

$S_{a}=$ the mass of the chopped after segregation of cutting length, $g$

\section{Machine productivity, $\mathrm{Mg} / \mathrm{h}$ :}

The running time of the experiment was measured by a stop watch. The machine productivity was calculated by dividing the chopping mass with the required time of chopped (ton/h).

\subsection{Chopping lengths:}

The theoretical length of a precision-cut forage chopper can be calculated according Kepner et al using the following equation:. (Kepener et al 2004)

$$
\mathrm{L}_{\mathrm{c}}=\frac{60000 \mathrm{~V}_{\mathrm{f}}}{\lambda_{\mathrm{k}} \mathrm{n}_{\mathrm{c}}}
$$


Where:

$$
\begin{array}{ll}
\mathrm{L}_{\mathrm{c}} & =\text { theoretical length of cut }(\mathrm{mm}) . \\
\mathrm{V}_{\mathrm{f}} & =\text { feed velocity }(\mathrm{m} / \mathrm{s}=\text { peripheral speed of feed rolls }) . \\
\lambda_{\mathrm{k}} & =\text { number of knifes on the cutterhead. } \\
\mathrm{n}_{\mathrm{c}} & =\text { rotational speed of cutterhead }(\mathrm{rev} / \mathrm{min}) .
\end{array}
$$

\section{Birds:}

A total of 960 (nine hundred and sixty) day-old broiler chicks (cobb) were used in this study. Chicks randomly distributed to four experimental treatments (120 chicks) each than divided into 3 replicates of forty chicks each. All checks were housed in separated floor pens under similar manage mental and hygienic conditions. Artificial lighting was maintained continuously during night without interruption.

\section{Cutting methods of bedding materials:}

\section{Experimental procedure:}

During experiment, body weight (BW), body weight gain (BWG), feed intake (FI) and feed conversion ratio (FCR) were calculated weekly. Also, the proportions of the bedding (nitrogen and moisture percentages, the $\mathrm{pH}$ value) were measured.

At the end of the growing period (42 days of age), 5 broilers chicks from each treatments were selected around mean average body weight of treatment and slaughtered for carcass evaluation among treatments. Carcasses were eviscerated and head and shank were removed, gizzar, intestine, ceca and spleen were dissected from the visceca and weighed. Each portion was expressed as a percentage of live body weight. Samples from meat of the carcass were taken for chemical analysis.

\section{Statistical analysis:}

The statistical analysis was carried out using the General Linear Model program 9GLM) of SAS (2004). The obtained data of chicks were subjected to factorial analysis of variance $(2 \times 4)$ according to the following model:

Where,

$$
\mathrm{Y}_{\mathrm{ijk}}=\mu+\mathrm{T}_{\mathrm{i}}+\mathrm{L}_{\mathrm{j}}+\mathrm{TL}_{\mathrm{ij}}+\mathrm{e}_{\mathrm{ijk}}
$$

$\mathrm{Y}_{\mathrm{ijk}} \quad=$ observation of the tested factor; 
$\mu \quad=$ overall mean;

$\mathrm{T}_{\mathrm{i}} \quad=$ The effect of cutting methods of bedding materials;

$\mathrm{i} \quad=1 \& 2$;

$\mathrm{L}_{\mathrm{j}} \quad=$ The effect of type of bedding materials

j $\quad=1 \ldots 4$;

$\mathrm{TL}_{\mathrm{i}} \quad=$ The interaction between cutting methods system and types of bedding materials and

$\mathrm{E}_{\mathrm{ijk}} \quad=$ Random error.

Differences among means were subjected to Duncan's Multiple Range test (Duncan, 1955).

\section{RESULTS AND DISCUSSION}

\section{1-The prototype productivity:}

The relationship between the cutting lengths $\mathrm{cm}$, and prototype productivity at different feed rates for rice and barley straws was shown in figure 4. At constant feed rate, the prototype productivity was increased with the increasing of cutting length of rice and barley straws. At $0.16 \mathrm{~kg} / \mathrm{s}$ feed rate, the productivity was increased from 0.56 to $1.9 \mathrm{t} / \mathrm{h}$ for rice, and from 0.41 to $1.39 \mathrm{t} / \mathrm{h}$ for barley when the cutting length increased from 1.5 to $5 \mathrm{~cm}$. At constant cutting length, the prototype productivity was increased with the increasing of feed rates of rice and barley straw. At $1.5 \mathrm{~cm}$ cutting length, by increasing the feed rates from 0.15 to $0.18 \mathrm{~kg} / \mathrm{s}$, the prototype productivity was increased from 0.53 to $0.64 \mathrm{t} / \mathrm{h}$ for rice, and from 0.41 to $1.39 \mathrm{t} / \mathrm{h}$ for barley.

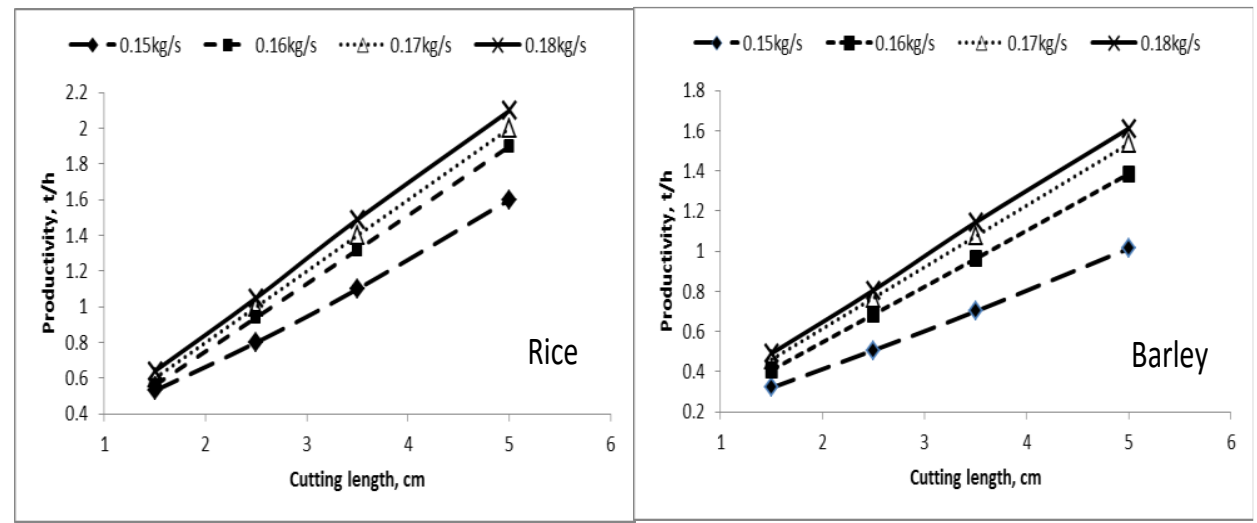

Figure 4: Effect of cutting length and feed rate on the prototype productivity for rice and barley stalks. 


\section{2-The prototype cutting efficiency}

Figure (5) shows the relationship between the cutting lengths $\mathrm{cm}$, and prototype cutting efficiency at different feed rates for rice and barley straws. At constant feed rate, the prototype cutting efficiency was increased with the increasing of cutting length of rice and barley straws. At $0.16 \mathrm{~kg} / \mathrm{s}$ feed rate, the cutting efficiency was increased from 73 to $82 \%$ for rice, and from 78.8 to $87 \%$ for barley when the cutting length increased from 1.5 to $5 \mathrm{~cm}$. At constant cutting length, the prototype cutting efficiency was decreased with the increasing of feed rates of rice and barley straw. At $1.5 \mathrm{~cm}$ cutting length, by increasing the feed rates from 0.15 to $0.18 \mathrm{~kg} / \mathrm{s}$, the prototype cutting efficiency was decreased from 75 to $70 \%$ for rice, and from 81 to 75.6 $\%$ for barley.

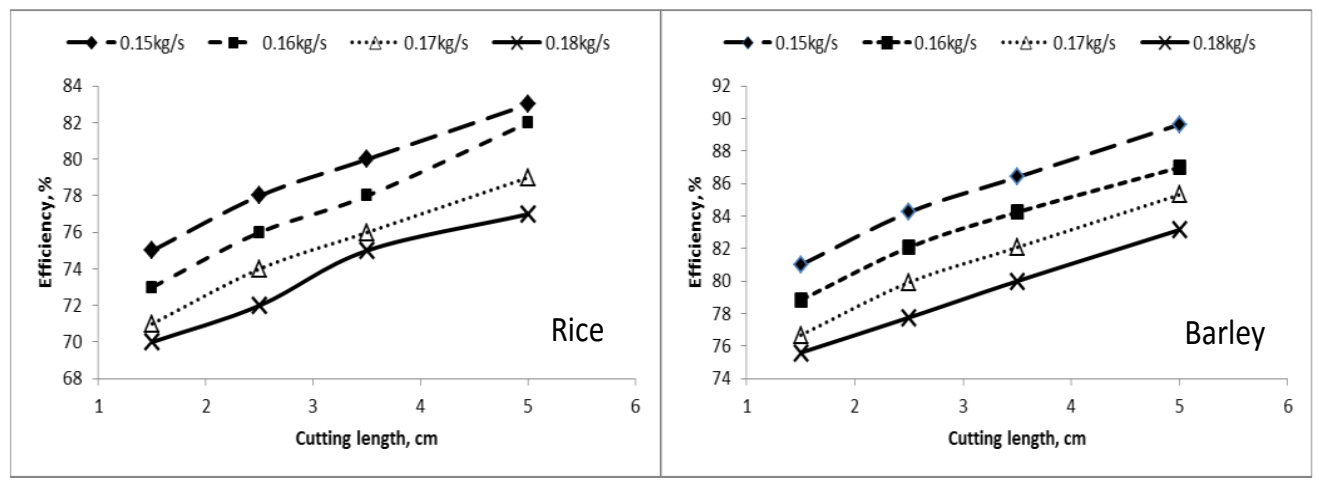

Figure 5: Effect of cutting length and feed rate on the prototype cutting efficiency for rice and barley stalks.

\section{3-The prototype rate of energy consumption}

Figure 6 shows the relationship between the cutting lengths $\mathrm{cm}$, and prototype rate of energy consumption at different feed rates for rice straw. At constant feed rate, the prototype rate of energy consumption was decreased with the increasing of cutting length of rice and barley straws. At $0.16 \mathrm{~kg} / \mathrm{s}$ feed rate, the rate of energy consumption was decreased from 9.35 to $4.99 \mathrm{~kW} . \mathrm{h} / \mathrm{t}$ for rice, and from 7.94 to 4.24 $\mathrm{kW} . \mathrm{h} / \mathrm{t}$ for barley when the cutting length increased from 1.5 to $5 \mathrm{~cm}$. At constant cutting length, the prototype rate of energy consumption 
was decreased with the increasing of feed rates of rice and barley straw. At $1.5 \mathrm{~cm}$ cutting length, by increasing the feed rates from 0.15 to $0.18 \mathrm{~kg} / \mathrm{s}$, the prototype rate of energy consumption was decreased from 9.84 to $8.36 \mathrm{~kW} . \mathrm{h} / \mathrm{t}$ for rice, and from 8.36 to $7.1 \mathrm{~kW} . \mathrm{h} / \mathrm{t}$ for barley.

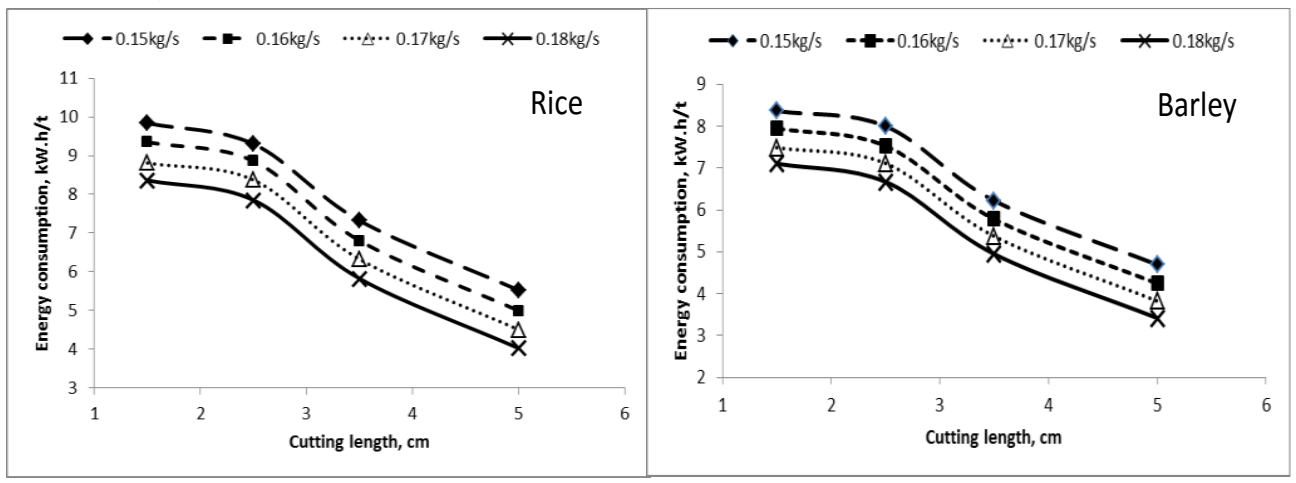

Figure 6: Effect of cutting length and feed rate on the prototype rate of energy consumption for rice and barley stalks.

\section{4-A comparison between prototype performance for chopping rice and barley stalks}

At a constant feed rate, moisture content $23 \%, 10 \%$ for rice and barley stalks respectively. The rice shave productivity was higher than the barley shave by $17 \%$ weight, the rice shave cutting efficiency was lower than the barley chafe by $8 \%$. And the rice chaff rate of energy consumption was higher than the barley by $20 \%$, Figure 7 .

\section{Growth performance:}

Results presented in Table (1) showed significant effect $(\mathrm{P}<0.05)$ of cutting system on all growth performance parameters. Body weight at 2 days of age, body weight gain and feed intake were significantly $(\mathrm{P}<0.05)$ higher with modified cutting system than with normal cutting system. However, feed conversion ratio was significantly $(\mathrm{P}<0.05)$ decreased to 2.17 in modified cutting system as compared to 2.28 in other cutting system.

As affected by different bedding materials, all growth parameters were significantly $(\mathrm{P}<0.05)$. Broilers grow on barley straw and barely + rice straw litters had the highest body weight and body weight gain. 
$\longrightarrow$ Rice -t+ Barley
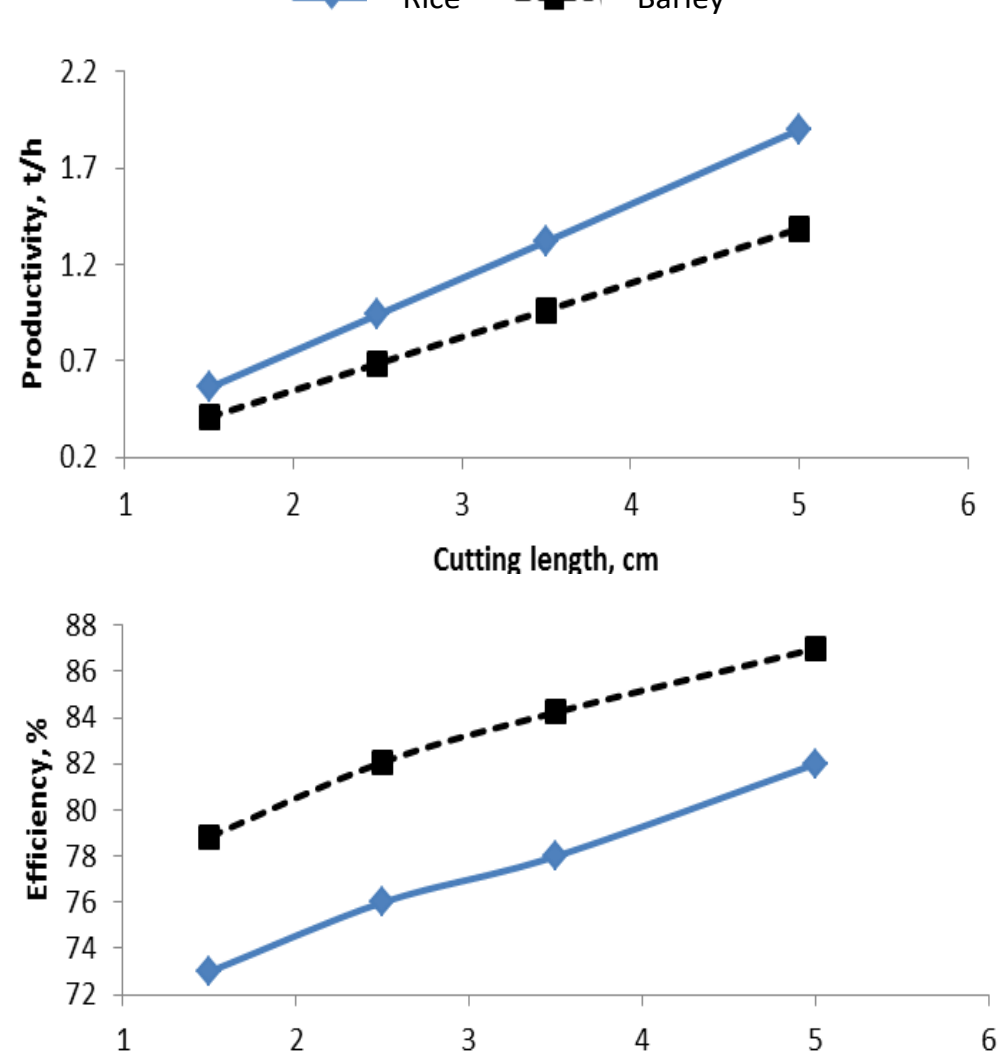

Cutting length, $\mathrm{cm}$

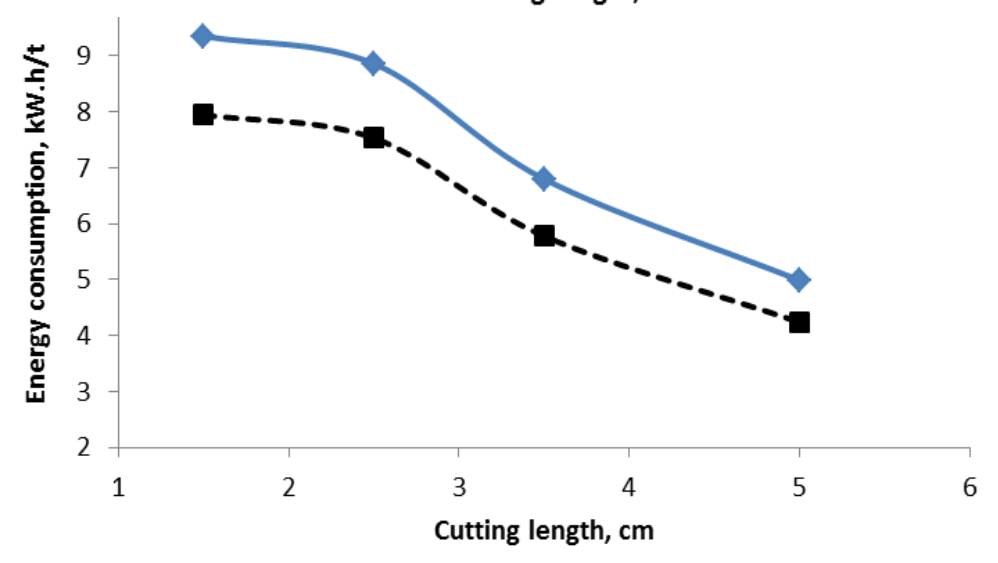

Figure 7: Show the relationship between cutting length $\mathrm{cm}$, and prototype productivity, cutting efficiency and energy rate at feed rate $0.16 \mathrm{kgs} / \mathrm{s}$ for both rice and barley straws. 
However, those grew on shaving woods liters alone had the lowest body weight and body weight gain.

These results agreed with those of Malone et al. (1983) and Billgilli et al. (1999b), who observed that bedding type can significantly affect growth performance. Also, Toghyani et al. (2010) indicated that body weight of broilers at 42 days was significantly $(\mathrm{P}<0.05)$ affected by litter type. On the other hand, several studies conducted by Brake et al. (1992); Lien et al. (1992) and Wyatt and Goodman (1992) indicated that the performance of birds were not affected by different types of bedding (recycled paper, pine shavings, refined gypsum and hard wood bark).

Results of feed intake and feed conversion are presented in (Table 2). Broilers grown on barley and shaving woods litters consumed the highest significant $(\mathrm{P}<0.05)$ amount of feed followed by those grown on rice straw litter. Feed conversion ratios were significantly $(\mathrm{P}<0.05)$ affected by bedding materials. Broilers raised on barley and rice straw litters had the best feed conversion (2.25 and 2.27, respectively). Our results may be due to the type of litter, age of birds and the experimental conditions. Tasistro et al. (2007) pointed out that there were no statistical differences in feed conversion ratio and mortality between each of the soft and coarse sawdust.

On the other hand, Confal et al. (2006a) observed that feed conversion was not different among treatments within nine consecutive flocks.

It is of interest to note that improving weight gain of growing broilers, regardless of cutting system or types of bedding material, was associated with increasing feed intake, but recorded the best feed conversion values.

The effect of interaction between cutting system and types of bedding materials on all growth indicating superiority of all growth parameters for modified of cutting system and broiler rearing on barely straw and barley and rice straw litters. 


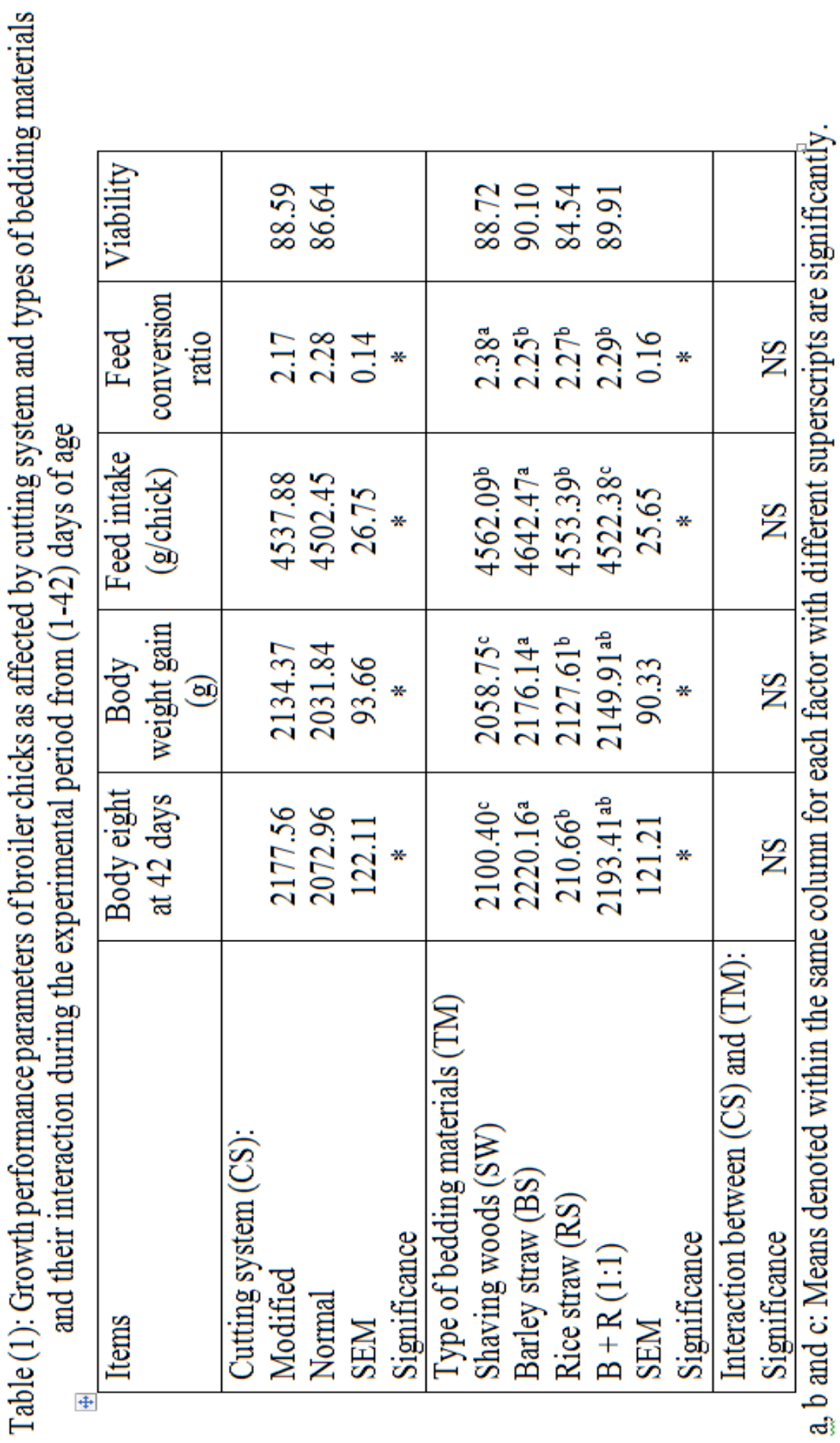




\section{CONCLUSIONS}

The prototype productivity increased with the increasing of cutting length at constant feed rate, and it increased with the increasing of feed rates at constant cutting length at constant feed rate. The prototype cutting efficiency increased with the increasing of cutting length at constant feed rate, and it decreased with the increasing of feed rates at constant cutting length. The prototype rate of energy consumption decreased with the increasing of cutting length at constant feed rate, and it also decreased with the increasing of feed rates at constant cutting length.

Results of this study indicated that, the product of the prototype of traditional bedding sources particularly rice straw can be used as bedding materials for rearing broiler during grown and finisher periods. Moreover, it could use mixture of (rice + barley) chaff as bedding materials in broiler house improved some broiler performance and litter characteristics as well as good impact on environmental condition and health status especially, under intensive broiler production in Egypt.

\section{REFERANCES}

Billgilli, S. F. , Montenegro, G. I., Hess, J. B., and Eckman, M. K. (1999b). Live performance, carcass quality and deboning yields of broilers on sand as alitter source. J. Appl. Poult. Res. 8:352-361.

Burke, G. B. , Peescatore, A. J. , Cantor, A. H. , Straw, M. T, Hua Hiangbai and Johnson, T. H. (1993). Newspaper as litter material and its effects on the performance of broilers. Jappl. Poult. Res. 2:154-158.

Elbery,A. M. Bayomy., A. M. "Limitation and Distribution of the Agricultural crop residues and It's Recycling Machines in Egypt. 2004.

Fundamentals of machine operation. "Hay and Forage Harvesting". Copyright (1981) Deer and Company, Moline, ILLinois

Habib, R.A.; Azzam; B.S. Nasr, G.M. and Kattab, A. A.. "The parameter affecting the cutting process performance of agricultural plants"., Misr J. Ag., (2002), 19(2): 361-372 
Hashish,A.E. hassan , M. A. and El-Mottalb, A. M. F., "Some Factors Affecting Performance of Chopping, Crushing And Grinding Equipment For Field Raw Materials', Misr J. Ag. Eng., July, pp. 669-682, 2002.

Kepener;R.A. Bainer R. and Barger, E.L. "Principle of Farm Machinery". $3^{\text {rd }}$ Avi- publishing. Co. Inc. West Port, Conn., U.S.A (2008).

Malone, G. W., Sims, T. and Gedamu, N. (1992). Quantity and quality of poultry manure produced under current management programes . Final report to the Delaware Department of Natural Resources and Environmental control and Delmarva poultry industry, Inc. University of Delaware, Reasearch and Education Center Georgetown, Delaware.

Okos ,M. R. , G. Narasimhan; R. K. Singh and A. C. Witnaurer (1992).

Food dehydration in D. R. Hedman and D. B. bund (EDS.). Hand book of food engineering, Newyork, Marcel Dekker.

Tien, R. J., Conner, D. E. and BIllgilli, S. F. (1992). The use of recycled paper chips as litter material for rearing broiler chickens. Poult. Sci. 71:81-87.

Toghyani M., Gheisar A., Modaresi M., Tebeidian S. A. and Toghyani, M. (2010). Effect of different litter material on performance and behavior of broiler chickens. Applied Animal Behaviour Science 122:48-52.

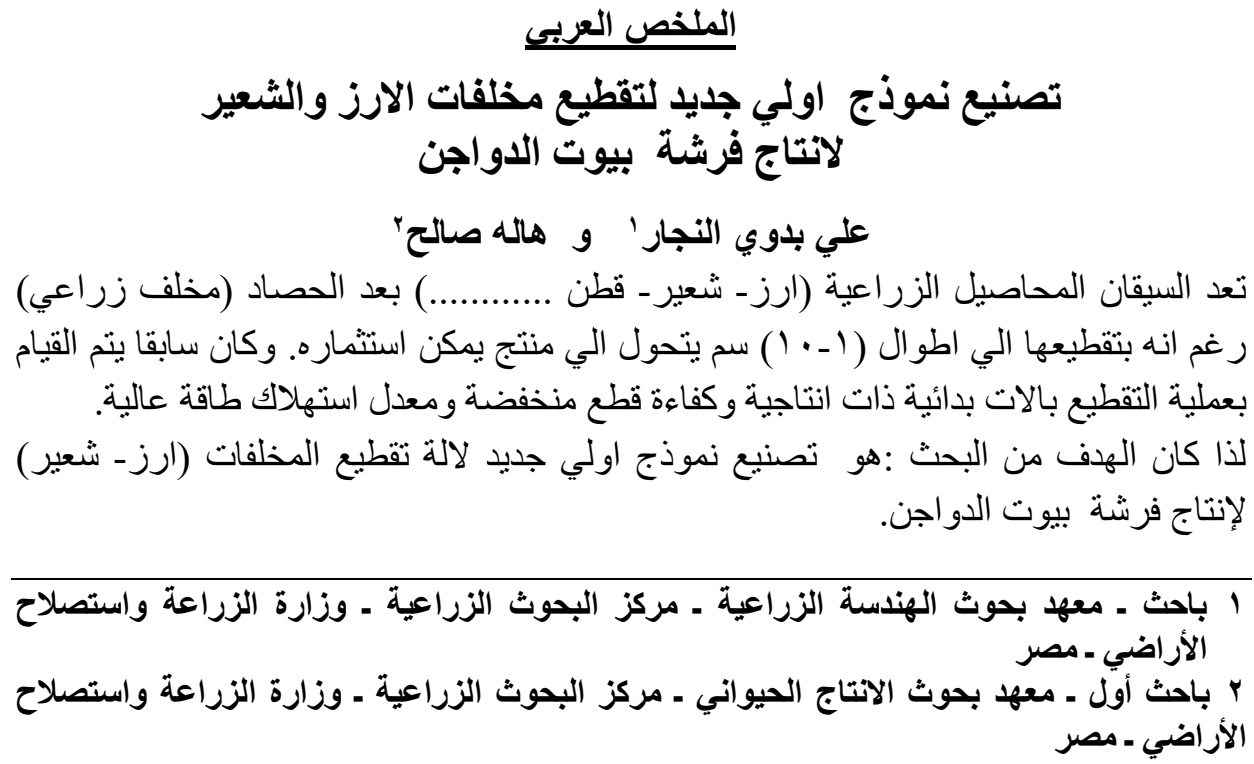


يمكن لهذا النموذج المتكون من (جهاز نقل القرة - جهاز التغذية - جهاز التقيع) التحكم في اطو ال القطع والوصول الي منتج بكفاءة قطع وانتاجية عاليتين ومعدل استهلاك قدرة منخفضة في ظل ظروف نشغيل امنه. وتم تصنيع النموذج الجديد عام با ب.r في مركز ميكنة الارز التابع لمعهد بحوث الهندسة الزر اعبة.

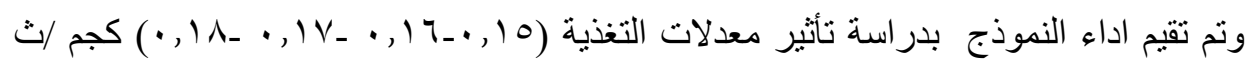

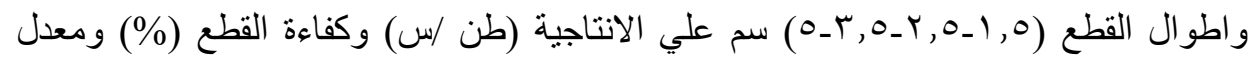

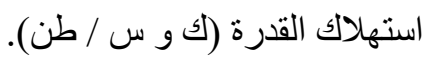
و اوضحت الدراسة الاتي:

بزيادة طول القطع من (0, 1 ـ0) سم عند معدل تغذية 7 ا, , كجم / ث ز زادت الانتاجية

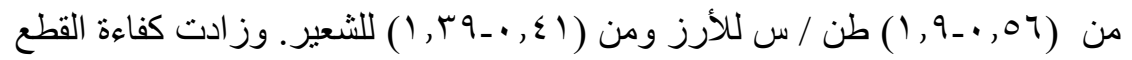

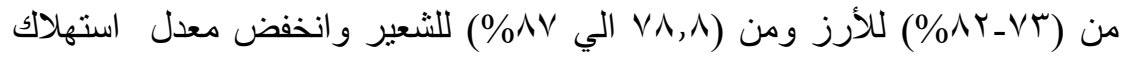

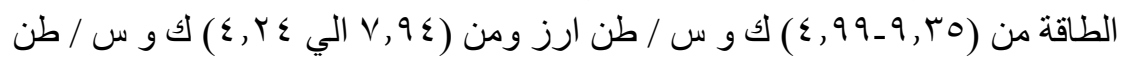
شعير.

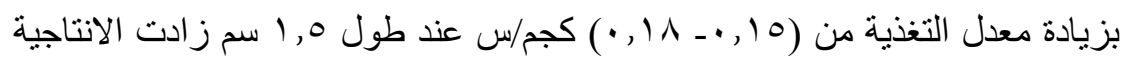

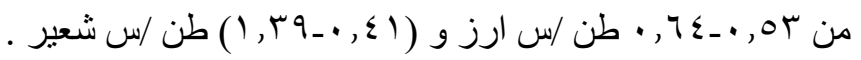

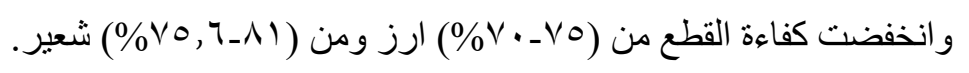

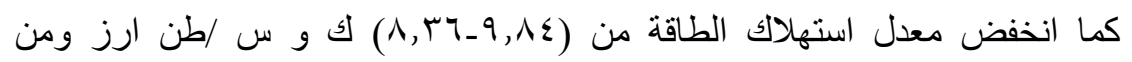

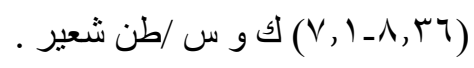

وباستخدام فرشة الارز و الشعير الناتج من القطع بنسبة (1: (1) و الطول 0 ر بسم ومقارنته بالفرشة

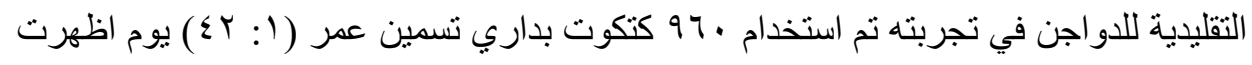

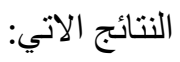

تحسين الاداء الانتاجي لكتاكيت التسمين وبجانب تحسينها لخواص الفرشة فضلا عن تأثثر ها الجيد علي الظروف البيئية وانعكاسها علي الحالة الصحية للطائر خاصة تحت ظروف الانتاج المكثف لبداري التسمين في مصر. 